\title{
MUSIC AND MIGRATION: COLOGNE CARNIVAL AS A STATE OF MIND
}

\author{
Birgit Ellinghaus, Monika Salzbrunn, Translator Katherine Booth, Alexandra Poméon \\ O’Neill
}

Université de Poitiers | «Revue européenne des migrations internationales »

2019/3 Vol. 35 | pages 33a à 40a

ISSN 0765-0752

ISBN 9791090426658

Article disponible en ligne à l'adresse :

https://www.cairn.info/revue-europeenne-des-migrations-

internationales-2019-3-page-33a.htm

Distribution électronique Cairn.info pour Université de Poitiers.

(C) Université de Poitiers. Tous droits réservés pour tous pays.

La reproduction ou représentation de cet article, notamment par photocopie, n'est autorisée que dans les limites des conditions générales d'utilisation du site ou, le cas échéant, des conditions générales de la licence souscrite par votre établissement. Toute autre reproduction ou représentation, en tout ou partie, sous quelque forme et de quelque manière que ce soit, est interdite sauf accord préalable et écrit de l'éditeur, en dehors des cas prévus par la législation en vigueur en France. Il est précisé que son stockage dans une base de données est également interdit. 


\title{
Revue européenne des migrations internationales
}

vol. 35 - $n^{\circ} 3$ et $4 \mid 2019$

Danses, musiques et (trans)nationalismes

\section{Music and Migration: Cologne Carnival as a State of Mind}

Musique et migration : le carnaval de Cologne comme état d'esprit Música y migración: el carnaval de Colonia en tanto modo de vida

\author{
Birgit Ellinghaus and Monika Salzbrunn
}

Translator. Katherine Booth and Alexandra Poméon O'Neill

\section{(2) OpenEdition}

Electronic version

URL: http://journals.openedition.org/remi/14741

DOI: $10.4000 /$ remi. 14741

ISSN: $1777-5418$

Publisher

Université de Poitiers

\section{Printed version}

Date of publication: 1 December 2019

ISBN: 979-10-90426-65-8

ISSN: 0765-0752

Electronic distribution by Cairn

\section{CAIRN, INFO}

CHERCHER, REPÉRER, AVANCER.

\section{Electronic reference}

Birgit Ellinghaus and Monika Salzbrunn, « Music and Migration: Cologne Carnival as a State of Mind », Revue européenne des migrations internationales [Online], vol. 35 - n³ et 4 | 2019, Online since 01 March 2020, connection on 23 November 2020. URL : http://journals.openedition.org/remi/14741 ; DOI : https://doi.org/10.4000/remi.14741

This text was automatically generated on 23 November 2020 .

(C) Université de Poitiers 


\title{
Music and Migration: Cologne Carnival as a State of Mind
}

\author{
Musique et migration : le carnaval de Cologne comme état d'esprit \\ Música y migración: el carnaval de Colonia en tanto modo de vida
}

Birgit Ellinghaus and Monika Salzbrunn

Translation : Katherine Booth and Alexandra Poméon O'Neill

\section{EDITOR'S NOTE}

The ERC ARTIVISM Project (www.erc-artivism.ch) has received funding from the European Research Council (ERC) within the framework of the European Union's research and innovation programme "Horizon 2020" (ARTIVISM - grant agreement No. 681880).

This column was translated from French to English with the support of the Institut des Sciences Sociales des Religions of the University of Lausanne.

1 As a 2,000-year-old city of immigration, Cologne and its festive life are marked by a wide variety of musical trends. The Carnival, which claims, among other things, to be a legacy of the cult of Dionysus, is first mentioned in city documents dating from 1341, and is characterised by mockery of the military authorities (who banned the festival during the Prussian occupation of the city) and blasphemy against the representatives of Catholic authority (Fuchs et al., 1972), often expressed in songs and parodies. As an emblematic institution of colonial multiculturalism, the Carnival brings together a heterogeneous music scene, and resonates with its history of encounters and passages.

\section{Cologne: Free City and Meeting Place}

2 The name "Köln" (Eng./Fr. "Cologne", It. "Colonia") is revealing of the origins of this city, which today has more than a million inhabitants. Founded in the year 50 AD by 
Agrippina the Younger as a Roman colony in the North and situated on the banks of the Rhine, Cologne has been a gateway and the world's ears for 2,000 years: it is a city of passage and encounters, first for legionaries, then for soldiers, merchants and, since the Middle Ages, pilgrims, and finally for tourists who have sometimes left their mark here (such as the "Eau de Cologne" created by the Farina family who arrived as merchants in Cologne in the $18^{\text {th }}$ century). Most of the time it has been a free city run by its inhabitants. Since its foundation, it has only on rare occasions been under foreign rule, for example during the occupation by Napoleon's troops. The Catholic Church although contested by a section of the population - has played a significant political, economic, cultural and moral role in the daily life of inhabitants. This can still be seen today in the cityscape, with the cathedral and twelve imposing Romanesque churches, as well as in the cultural landscape: the local Church, which is very critical of the Vatican, mostly practises a liberal "Rhineland Catholicism" and is active as an organiser and funder. Meanwhile, the "Freie Szene" (freelance artists scene), a broad "free" music scene with all kinds of styles and only scant public subsidies compared to the Opera and Philharmonic, is the beating heart of a particularly dynamic musical creation.

3 Yet, history has not spared this city, which proudly promotes its multicultural origins ${ }^{1}$ : it has been flooded on several occasions, set alight during wars and almost completely destroyed by the bombings of the Second World War. The most recent disaster to date: in 2009, significant documents for the history of music were lost in the collapse of Cologne's municipal archives, following errors in the construction of an underground railway line, compounded by corruption. This illustrates another facet of Cologne's reputation, perceived due to its festive culture as the most Italian city north of the Alps: the "Klüngel", a culture of mutual assistance marked by conflicts of interest.

Based on this history, Cologne is one of the German cities embodying a strong and ancient connection between musical traditions from Roman times to the present day, and the local musical culture, marked by dialect. The city has always been home to thousands of amateur and professional musicians of various origins who, even today, actively refer to the diverse sources of Cologne's musical history.

\section{Multiple Historical Sources}

Musicians refer to mythical images of musicians and instruments from the Roman period, which are very present in museums and churches as well as in the street, such as the famous mosaic dedicated to Dionysus in the Romano-Germanic Museum next to the cathedral.

6 There are also all the legendary stories of the "Veedel" people (working-class neighbourhoods, first destinations of labour immigrants), who produced a particular kind of popular poetry, together with profound, critical and humorous songs. Kölsch, the traditional Cologne dialect and language of the people, plays an important role in this respect. It has incorporated many elements of the linguistic diversity that has enriched the city throughout the ages, firstly with the French language, passed on primarily by the elites in the $16^{\text {th }}$ and $17^{\text {th }}$ centuries and then through the 12,000 revolutionary soldiers, and later the Napoleonic soldiers present in the city (1794-1814) (Cornelissen, 2019). Kölsch is characterised by a specific intonation, considered songful and Rhenish. It is employed as an eloquent rebellion against the 
authorities and as a form of resistance based on concise humour. The Krätzcher is its musical embodiment.

7 Originally, Krätzcher (literally "to scratch", metaphorically "to provoke") was a form of satirical poetry in the Kölsch dialect. These poems were taken up again at the end of the $18^{\text {th }}$ century by the Rhineland minstrels, and were sung with musical accompaniment in moderation. Today, Krätzcher songs are one of the oldest forms of traditional oral music in the Rhineland. During World War II, Krätzcher reached new heights as a critical and humorous format, expressing with limited means what the people did not dare to say openly. The instrumental accompaniment to the songs was generally simple, but the lyrics, often polysemous, reflected a certain philosophy in a laconic way and gave reason to smile and reflect.

Contrary to many folk music traditions, the Krätzcher was not instrumentalised by the Nazis. On the contrary, it was an expression of resistance. After the Second World War, Krätzcher almost completely disappeared from the scene. While these songs were not taboo in post-war Germany, they were considered old-fashioned, because they did not respond to the need for harmony and to live under the illusion of a heile Welt (translatable as "healthy and comforting world") during the years of the economic miracle ("Wirtschaftswunderjahre").

9 It was not until the 1980s that Krätzcher experienced a renaissance, sparked by the leading Kölsch dialect rock band, Bläck Fööss, whose musicians included Krätzcher in their repertoire. Not only was the public made aware of this old style of song from Cologne, but it also inspired many other artists. Today, Krätzcher once again forms part of the repertoire of the local music culture. Among the most important representatives of this tradition are Turkish, Brazilian and Nigerian rappers living in Cologne. The Kölsch dialect has thus become (once again) the identity card of the city and the representative element of the local music scene. In a carnival show devised "from the perspective of newcomers" in the form of a political cabaret "between cultures", the "Immi-Sitzung", the new "Krätzcher", are accompanied by a wide variety of musical trends. The artists' motto is "Jede Jeck is von woanders" ("Every fool comes from somewhere else") ${ }^{2}$, a variation on the well-known phrase "Jede Jeck is anders" ("Every fool is different"). Both mottos embody the open-mindedness of the city and an awareness that all of its residents are (children of) immigrants.

10 These sources, including the Krätzcher, are the basis of a musical biotope and urban sound specific to the city of Cologne, which are expressed in a variety of musical forms and in the Carnival, an emblematic and unifying institution.

\section{Carnival: A Political Declaration in Support of Openness towards Others}

11 The particular value of the Cologne Carnival is that it is a cathartic festival, bringing together all social groups and musical genres in its musical biotope on an annual basis and attracting more than 1 million visitors each year. It represents a time in the year when the rules of life are challenged, when people get together at parties, when new things are created. In 2015, UNESCO added the Cologne Carnival to the National List of Intangible Cultural Heritage: 


\begin{abstract}
"The Carnival spreads feelings of joy and gives the impression of being part of a strong community. Particularly during times of social upheaval, its power of integration has been proven: the festival provided great impetus in the post-war period of reconstruction of the city. The carnival culture of hospitality is very strong. Migrants find easy access to the regional community. Within the "jeck" [fool] community, dressing up to slip into other roles, taking part in wild celebrations is as much a part of the carnival as voluntary social commitment. The history of the carnival celebrations in the Rhineland goes back to the beginning of the $13^{\text {th }}$ century. It was defined as a time period before Lent in the Christian year. [...] At the beginning of the $19^{\text {th }}$ century, a secular form of the Carnival developed in Cologne. Since that time, on Carnival Monday, a masked parade has imitated and caricatured the great military parades"3.
\end{abstract}

During the Carnival, other musical specialities from Cologne can be identified: the "Schunkeln", brass bands, marching bands and drum ensembles. In the parades, the festive music comes mainly from military marches, played by brass bands and drum ensembles from the suburbs or villages around Cologne, but also from samba and batucada bands. These groups move spontaneously from bar to bar and accompany the parades through the different neighbourhoods. In traditional balls held in halls and tents, a particular form of waltz can principally be heard. There is no dance floor, and since people cannot get out of their rows of seats, they have developed a dance that can be performed while sitting: the "Schunkeln". The spectators are seated on benches around long tables and watch large orchestras perform a programme of joyful celebration. Spectators' arms are linked to those of the people sitting to their right and left and they sway together while singing amusing songs. At these traditional balls, the origin of carnival-goers is of no importance. It is neither a matter of assimilation nor of active integration of migrants. The motto is "Every Jeck is different", which embodies the value of otherness, no matter where it comes from. In 2008-2009, several of Cologne's emblematic monuments were depicted as people engaged in "Schunkeln", with interlocking arms, on the official medal of one of Cologne's largest districts: the new Cologne Mosque, one of the biggest and most visible in Europe, was represented (ten years before its official opening!) next to the cathedral, the television tower and the local Heliosturm monument.

13 In Cologne, carnival is thus a state of mind, a political declaration of openness to others, embodied by musical diversity and a form of anarchism and permanent transgression ${ }^{4}$. Around this Carnival, a variety of musical forms, and expressions through sound of the value of multiculturalism, germinate and evolve.

\title{
A Multicultural Biotope Inspiring a Variety of Musical Expressions
}

Cologne's music scene, like those of other cities, includes a wide variety of musical genres, such as jazz and improvised music, rock and pop, baroque music, avant-garde contemporary music, electronics, classical music and traditional and world music. Yet, each musical genre uses the Kölsch dialect for contemporary creations. Freethinkers and rebels express themselves in dialect in their anthems against racism and xenophobia, reaching a recent peak with the "Arsch huh" movement. This movement - literally "ass up", metaphorically "get moving" against racism and rightwing extremism - was born in 1992 after the attacks on refugees in Hoyerswerda in the 
former GDR - and its local and international heroes, BAP, Bläck Fööss, Brings and Höhner - and has been drawing crowds for twenty-five years. United above and beyond their quarrels at a time when racism was emerging in the form of a series of deadly xenophobic attacks for the first time since the end of World War II in Germany, these carnival music groups and/or rock bands singing in Kölsch, assembled 100,000 spectators on 9 November 1992 in the city centre to take a stand against racism. On the anniversary of the 1938 "Kristallnacht" (a pogrom against the Jewish population), the anthem "Arsch huh, Zäng ussenander" promoting living together and civil courage was sung for the first time. The song was written in just a few days, in reaction to the attacks, by Vassilios "Nick" Nikitakis and Wolfgang Niedecken, singer in the world-famous BAP band. Jean Jülich, a resistance fighter and member of the "Edelweisspiraten" also took part in the event. This symbolic and personal link between carnival protagonists, World War II resistance fighters and musicians from migrant backgrounds is a recurring theme, as shown by the examples of "Humba" and the "Zigeunerfestival".

\section{Affirming Multiculturalism through "World-Music": "Humba \& Family"}

Since the early 1990s, the main idea of the "Humba" 5 platform has been to assert the musical diversity at the heart of Cologne's popular, collective, vibrant and sonorous tradition. This multiculturality is expressed in the relationship between so-called "world music/Weltmusik" and the local musical traditions of the city of Cologne, of which the carnival tradition is the most powerful.

16 The initial impetus for "Humba \& Family" activists came from a trip to Ivory Coast in 1992 for the purposes of musical research. They found that the locals showed little interest in their traditional music, which was - and still is - the key to many musicians' activities in Cologne and West Africa. The Humba activists asked themselves: is it acceptable to ask Africans to better nurture their musical traditions when in Germany a large part of the population is unaware of the local musical traditions in most regions?

Preliminary research was carried out on the music of the Cologne Carnival and in particular the traditional music played in the city. The aim was to gain a better understanding of the roots of certain musical movements, exciting new trends beyond folklore and FakeFolk. It was also a question of grasping the effects of the diversity of music resulting from migration both on the transnational circulation of music and on local creation.

18 The research was supported by WDR Radio and led to a live presentation during the 1994 carnival, under the title "Humba Party", and the first CD compilation. Since then, the "Humba \& Family" movement has created a fertile environment for musical experimentation. Musicians of diverse origins are fully recognised as actors of urban musical expression, and as interpreters of carnival music, enabling audiences to dance, sing or laugh.

19 How did this musical fusion in Cologne become a lively and well-established popular tradition? For some artists it was easy, because they came from another carnival culture, such as Brazil, Cuba, etc.; but other musicians had to transform their 
traditional style, either musically or by working with the Kölsch dialect, which is very important for the local culture and especially for the carnival. They have produced and created rap, reggae, samba or oriental songs in Kölsch, and Krätzcher in other languages. Instead of turning to genres such as rock or English-speaking pop, the Humba movement embodies the soul of Cologne. Its mission goes far beyond carnival, as it seeks to liberate local musical traditions from the negative associations with the Nazi era that still existed in the 1990s and 2000s, and to transgress class differences. Today, large grassroots events such as "Loss' m'r singe" ("Let's sing") fill Cologne's largest stadium, where 40,000 people gather to sing Christmas carols, played by carnival groups among others. Carnival not only lasts the whole year with these pretexts for getting together, partying and singing, but it also represents a state of mind that allows people to break rules all year round.

Following the initial success of the carnival festivities organised by Humba, fans of the music of the Humba movement contributed their knowledge on other occasions, inspired by the carnival season. In 2001, fans and activists launched small grassroots summer festivals in suburban gardens, the "Humba-Schrebergarten-Tour", each featuring at least one group in the local Cologne style and an ensemble of music from elsewhere - traditional African, Persian classical, Indonesian gamelan, etc. - all based in the city or the region.

Subsequently, activities were extended to other aspects of local urban life. For example, they focused on the music of the Edelweißpiraten, a youth resistance movement under the Nazi dictatorship. Originally it was a major musical movement in Cologne, which inspired Humba activists to get in touch with former Edelweißpiraten and to produce a festival with them and other music groups to pay tribute to the anti-Nazi struggle. Since then, the Edelweißpiraten-Festival ${ }^{6}$ has become a major expression of Cologne's intangible urban heritage and cultural diversity.

\section{Valorising the Multiplicity of Sounds from (Trans)local Communities}

Another facet of this local urban life at the crossroads of local and migratory traditions that Humba has explored concerns the collaboration with the gypsy community in Cologne to preserve and promote the various aspects of their culture. Similar work has been carried out with the local Sinti community, present for several generations, despite the fact that their members have often been victims of exclusion. Today, upending a long-standing stigma, they proudly call themselves "Zigeuner" and have given this name to the "Rheinisches Zigeunerfestival"'. The festival features concerts around the historic horse-drawn carriages and chariots, which the Nazis stole from the family of Markus Reinhardt, a gypsy family based in Cologne. The festival also brings together trans-local gypsy communities from many countries, showing both diversity and unity.

All these activities carried out by Humba \& Family are forms of "public laboratories" to experiment with traditional and new sounds, and to interact with local musicians and their friends from all over the world ${ }^{8}$.

Besides the carnival itself, there are also soundscapes of the so-called "Immis", migrant and refugee newcomers who make up almost $40 \%$ of the population. In Cologne, rather 
than one majority migrant group, there are many communities: descendants of Germans who grew up in Poland, Russia or the Ukraine, exiles from Iran and Afghanistan since the 1990s, migrant workers from Italy and Greece since the 1960s. Armenians, Kurds and Turks represent other major cultural groups, as well as Asians, Latinos and, since 2015, Syrians, Yezidis from Iraq and migrants from West and North Africa. With the contribution of new musical instruments and styles, the city is perceived as one of the symbols of tolerant multiculturalism, both from a self-discourse and an electoral point of view ${ }^{9}$. Some of these new artists conserve their traditional music in their new place of residence on the Rhine and preserve the traditional and/or ritual dimension of their music, mainly played for their own community.

Others embark on the search for a new musical home and participate in intercultural groups and "Brauchtum" ("customs") projects: a cultural practice that is locally rooted, but also cosmopolitan and progressive. Professions or population groups also have their own musical spokespersons, such as, for example, Köbes Underground (Köbes: "waiter" in the Cologne brasseries).

Thus, all these musical protagonists, with their own seeds of sound, contribute to turning the city of Cologne into a veritable Tower of Babel, in particular when social movements such as the Edelweißpiraten-Festival, in memory of Cologne's resistance during the Nazi dictatorship, the Rheinisches Zigeunerfestival of the local Sinti and Roma, or the Newroz Festival, the "Spring of Cultures" of the Kurdish and IranianKölsch scene, are set in motion.

\section{BIBLIOGRAPHY}

Cornelissen Georg (2019) Kölsch. Portrait einer Sprache, Köln, Greven Verlag.

Fuchs Peter, Schwering Max-Leo und Zöller Klaus (1972) Kölner Karneval. Zur Kulturgeschichte der Fastnacht, Band 1, Köln, Greven Verlag.

Salzbrunn Monika (2014) How diverse is Cologne Carnival? How migrants appropriate popular art spaces, Identities, 21 (1), pp. 92-106.

\section{NOTES}

1. The city's official website concludes the summary of its Roman history with the statement "Already at that time Cologne was multicultural" (https://www.stadt-koeln.de/politik-undverwaltung/presse/agrippina-kaiserin-aus-koeln). In addition, twenty years ago the tourist office launched a campaign entitled "The first people of Cologne were foreigners" (Translated from German by Monika Salzbrunn).

2. These phrases in quotation marks are all taken from https://www.immisitzung.de/index.php and were translated from German by Monika Salzbrunn. 
3. Translation into English from French translation of text from the website https:// www.unesco.de/kultur-und-natur/immaterielles-kulturerbe/immaterielles-kulturerbedeutschland/rheinischer-karneval

4. The twenty or so "official" and "alternative" Christmas markets also embody this carnival spirit: several gay markets with glitzy decoration, an afterwork market organised by a Dutchman on a plot of land on the edge of a cemetery, where children go on carousel rides and parents take part in the "Schunkeln", etc.

5. www.humba.de

6. www.edelweisspiratenfestival.de

7. www.zigeunerfestival.de

8. A large number of translocal gypsy families have their base in Cologne, to the extent that they bury their dead in large family vaults. On some of the gravestones of the large western cemetery, "Westfriedhof", horse-drawn carriages or large sedans are engraved as a reminder of the nomadic past and present. Families meet regularly at the cemetery to maintain the vaults, but also to spend time together in these places, which resemble large parks with century-old trees. This cemetery, which is adjacent to the Jewish cemetery, also has a Muslim section (Observations by Monika Salzbrunn, Westfriedhof, 23-24/12/2019).

9. For an analysis of actions in support of undocumented migrants during the Cologne Carnival, see Salzbrunn (2014). For the past century, the vote for the extreme right has been lowest in the Rhineland, especially in Aachen and Cologne.

\section{INDEX}

Mots-clés: musique, migration, carnaval, musiques du monde, multiculturalisme, patrimoine immatériel

Palabras claves: música, migración, carnaval, músicas del mundo, multiculturalismo, patrimonio inmaterial

Keywords: music, migration, carnival, world music, multiculturalism, intangible heritage

\section{AUTHORS}

\section{BIRGIT ELLINGHAUS}

Director, alba KULTUR, Zwirnerstr. 26, D - 50678 Cologne, Germany; birgit@albakultur.de

\section{MONIKA SALZBRUNN}

Sociologist and anthropologist, Professor of Religions, Migration, Diasporas and Director of the ERC ARTIVISM Project, University of Lausanne, Anthropole 5067, 1015 Lausanne, Switzerland; monika.salzbrunn@unil.ch 